\title{
PETA PENAKLUKAN WILAYAH BAGIAN TIMUR PULAU JAWA OLEH BELANDA BERDASARKAN TEKS BABAD BASUKI
}

\author{
Ghis Nggar Dwiadmojo dan Endang Nurhayati \\ Universitas Negeri Yogyakarta \\ email: ghisnggar@yahoo.com
}

\begin{abstract}
(Title: Map of Conquest of the Eastern Part of Java by the Dutch Based on the Text of "Babad Basuki"). One of Javanese manuscript's genre is babad. Babad is a traditional Javanese history. This research's data is qualitative data. Qualitative data in this research was Babad Basuki text in the Babad Basuki and Bandawasa (BBB) handscripts. This handscripts is PNRI collection with $K B G 333$ collection number. The purpose of this study were to describe the $K B G 333 B B B$ manuscript, summarize the story of regional conquest in Babad Basuki text, and make map territorial conquests based on the text of Babad Basuki. The method used are heuristic and hermeneutic reading. The territories conquered by the Dutch in the text were Banger, Senthong, Lumajang, Penarukan, Blambangan, Nusa, Klathakan, and Watu Ula. The text was copied in the 19 th century. Based on the text, these areas were once important areas to be conquered but now become names of town, district, village, and sub-village.
\end{abstract}

Keywords: peta, conquest, babad basuki, Eastern Part of Java.

\section{PENDAHULUAN}

Naskah-naskah Jawa mempunyai isi yang beragam. Keberagaman naskah Jawa ini, salah satunya, ditunjukkan dalam pengantar Katalog Induk Naskah-naskah Nusantara Jilid 1 Museum Sonobudoyo, Yogykarta, yang dsunting oleh Behrend. Dalam pengantar katalog tersebut, naskah-naskah koleksi Museum Sonobudoyo dibagi menjadi beberapa kategori berdasarkan isinnya, yaitu sejarah, silsilah, hukum dan peraturan, wayang, sastra wayang, sastra, piwulang dan suluk, Agama Islam, primbon dan pawukon, bahasa, musik, tari-tarian, adat istiadat, lain-lain. Sementara dalam Katalog Naskah-naskah Koleksi Perpustakaan Nasional, kategori berdasarkan nama kolektor dan bahasa teksnya (lihat Behrend, 1998: v)

Salah satu di antara kategori-kategori naskah berdasarkan isinya adalah sejarah atau babad. Behrend (1990: X) berpendapat bahwa naskah yang termasuk kategori naskah adalah naskah yang mencakup segala macam babad yang menceriterakan peristiwa historis dan legendaris, sejak penciptaan dunia sampai dengan Perang Dunia I.

Beberapa penulisan babad dalam sejarah lokal di Indonesia lebih merupakan rekam- an pada asal-usul atau genealogi keluarga penguasa di wilayah tersebut (Kartodirdjo, 2001: 90). Dalam sastra Jawa tradisional, sastra sejarah disebut babad, yang dipahami sebagai asal sebuah sejarah lokal (Pudjiastuti, 2008: 2-3 dalam Pudjiastuti, 2015: 3). Sementara Djajadiningrat (1995: 58) menyebutkan bahwa tradisi sejarah tertulis dikenal dalam bahasa Jawa sebagai babad, sejarah, dan serat kanda yaitu cerita-cerita tertulis. Beberapa pendapat di atas mengungkapkan bahwa babad mengandung unsur sejarah tertulis, lingkup lokal. Pengertian lokal bisa berarti asal usul nama suatu daerah atau keturunan penguasa daerah.

Namun tidak sedikit juga yang menyangsikan naskah-naskah kuna bisa dijadikan sebagai sumber sejarah, yang dengan kata lain informasi-informasi di dalamnya tidak bisa dipercaya sebagai sebuah kebenaran. Genre sastra sejarah Nusantara dianggap tidak dapat dijadikan sebagai pijakan penulisan sejarah, karena mengandung unsur dongeng, mitos dan legenda (Ibrahim, 1986). Lebih lanjut lagi dijelaskan bahwa meskipun judul khasanah itu babad atau sajarah belum tentu dapat dijadikan sumber dalam penulisan sejarah karena di dalamnya bercampur antara fakta dan fiksi (Ibra- 
him, 1986). Selain itu Kuntowijoyo $(1999,128)$ menjelaskan bahwa historiografi tradisional seperti babad, hikayat, dan lontara, bernilai sejarah yang berbeda-beda karena bercampur unsur mite dan legenda dalam sejarah dan mengandung banyak anakronisme, sehingga perlu verifikasi. Dari pernyataan di atas jelas bahwa pembaca (terutama sebagai peneliti) harus jeli dalam membaca dan memilah informasi dalam naskah. Apalagi jika pembacaan bertujuan untuk mencari kebenaran sejarah di dalamnya.

[...] naskah Jawa sering mengalami penyalinan, penggubahan, dan penambahan isi sesuai kepentingan penulis. Otentisitas naskah menjadi masalah dalam mengkaji suatu naskah. Oleh sebab itu, sejarawan selalu menggunakan kritik sumber (Abdurrahman, 1999: 55-67 dalam Adi Putra Surya Wardhana, 2017). Ada perbedaan dalam metodologi penelitian filologi (atau kajian naskah) dan penelitian sejarah. Penelitian filologi berpusat pada suntingan teks dan terkadang juga sampai terjemahan untuk mengetahui isinya. Sementara untuk mengetahui kebenaran informasi di dalamnya, sejarah memiliki metodologi tersendiri, yang salah satunya adalah kritik sumber.

Data penelitian ini adalah data sekunder yaitu alih aksara teks Babad Basuki dalam naskah Babad Basuki dan Bandawasa dengan kode naskah $K B G 333$. Untuk selanjutnya naskah ini disingkat $B B B K B G 333$. Naskah ini tersimpan di Perpustakaan Nasional Republik Indonesia. Naskah ini termasuk ke dalam kategori naskah babad. Alih aksara Babad Basuki ini telah dibuat oleh Komari pada tahun 2014, dicetak dalam buku Babad Basuki dan Bandawasa (Deskripsi, Alih Aksara, dan Alih Bahasa), diterbitkan secara terbatas (tidak untuk diperjualbelikan) oleh Perpustakaan Nasional Republik Indonesia.

Teks Babad Basuki dalam naskah $B B B$ $K B G 333$ ini bercerita tentang penaklukan tentara kolonial Belanda di wilayah-wilayah di bagian timur Pulau Jawa. Cerita tentang penaklukan ini dijabarkan secara deskriptif. Selain dijelaskan secara deskriptif, cerita dalam babad ini juga mengandung mitologi yang berbau mistis. Cara lain menjelaskan ringkasan cerita penaklukan ini, agar lebih mudah dipahami, adalah dengan menggambarkannya ke dalam sebuah peta.

Kata peta (bahasa Indonesia) dalam bahasa inggris disebut map. Secara etimologi kata map berasal bahasa Yunani yaitu mappa yang berarti taplak meja. Dalam KBBI peta berarti suatu gambaran atau lukisan pada kertas yang menunjukkan letak tanah, laut, sungai, gunung, dna lain sebagainya; representasi melalui gambar dari suatu daerah yang menyatakan sifat, seperti batas daerah, sifat permukaan, dan denah. Berdasarkan informasi-informasi di atas dan ditambah pendapat ICA (International Cartographic Association), Prihandito (1998), Erwin Raisz (1948), Badan Koordinasi Survei dan Pemetaan Nasional atau BAKOSURTANAL (2005), dan F.J Mounkhous dan H.R Wilkinson dapat dijelaskan bahwa pengertian peta adalah gambaran permukaan bumi pada bidang datar yang memuat data informasi geografis dan administratif yang diskalakan dan diberi tulisan penjelas.

Penaklukan berasal dari kata dasar takluk. Dalam Kamus Besar Bahasa Indonesia kata takluk berarti mengaku kalah dan mengakui kekuasaan pihak yang dianggap menang, menyerah kalah kepada, tunduk kepada. Imbuhan berupa awalan $p e$ - dan akhiran -an berfungsi untuk menyatakan tempat atau menyatakan proses. Imbuhan pe- dan -an dalam kata penaklukan berarti proses, jadi penaklukan bermakna proses takluk.

Peta penaklukan dalam hal ini berarti gambaran urut-urutan penguasaan wilayah di bagian timur Pulau Jawa oleh pemerintah kolonial Belanda. Informasi-informasi mengenai urut-urutan wilayah yang dikuasai oleh pemerintah kolonial Belanda ini terdapat dalam teks Babad Basuki naskah BBB KBG 333. Berdasarkan penjelasan di atas maka tujuan penelitian ini adalah mendeskripsikan naskah $B B B K B G$ 333, meringkas isi cerita teks $B a$ bad Basuki dalam naskah $B B B K B G 333$ yang berisi penaklukan daerah-daerah di wilayah timur Pulau Jawa, dan membuat peta penaklukan wilayah dalam teks Babad Basuki dalam naskah $B B B K B G 333$. 


\section{METODE}

Data penelitian ini adalah data kuantitatif. Data kuantitatif ini berupa kata-kata teks Babad Basuki dalam naskah BBB KBG 333. Data kualitatif berupa kata-kata dalam teks ini kemudian dikategorisasikan berdasarkan tempat-tempat yang dikuasai oleh tentara kolonial Belanda. Data yang tidak termasuk ke dalam kategori di atas kemudian direduksi. Metode yang dipakai dalam penelitian ini adalah metode deskriptif.

Untuk mengakategorisasikan data sesuai kategori di atas, teks dibaca secara heuristik dan hermeneutik. Pembacaan heuristik berarti teks dibaca dengan teliti kata per kata untuk sampai pada pemaknaan arti. Pembacaan teks secara hermeneutik berarti teks dibaca keseluruhan, disesuaikan dengan konteks, dan kemudian dimaknai artinya.

\section{HASIL DAN PEMBAHASAN Hasil}

Naskah Babad Basuki dan Bandawasa merupakan koleksi Perpustakaan Nasional Republik Indonesia dengan nomor koleksi $K B G$ 333. Teks naskah Babad Basuki dan Banda- wasa ini terdiri dari dua bagian yaitu Babad Basuki (halaman 1-29) dan yang kedua Babad Bandawasa (hal 31-69). Teks disalin pada abad ke 19.

Urutan nama daerah di wilayah timur Pulau Jawa yang ditalukkan oleh Belanda adalah Banger, Senthong, Lumajang, Penarukan, Blambangan. Dari Blambangan teks menceritakan bahwa Belanda menaklukkan tiga wilayah sekaligus, yaitu Klathakan, Watu Ula, dan Nusa. Dari cerita di atas dapat digambarkan rute panaklukan wilayah-wilayah di bagian timur Pulau Jawa. Penggambaran tersebut lebih mudah jika dijelaskan dalam bentuk peta. Adapun peta penaklukan wilayah di bagian timur Pulau Jawa seperti yang diceritakan dalam Babad Basuki di atas sebagaimana disajikan pada Gambar 1.

\section{Pembahasan}

Naskah Babad Basuki dan Bandawasa merupakan koleksi Perpustakaan Nasional Republik Indonesia dengan nomor koleksi $K B G$ 333. Dari studi Katalog Induk Naskah-naskah Nusantara Jilid 4 Perpustakaan Nasional Republik Indonesia dan keterangan dalam terje-

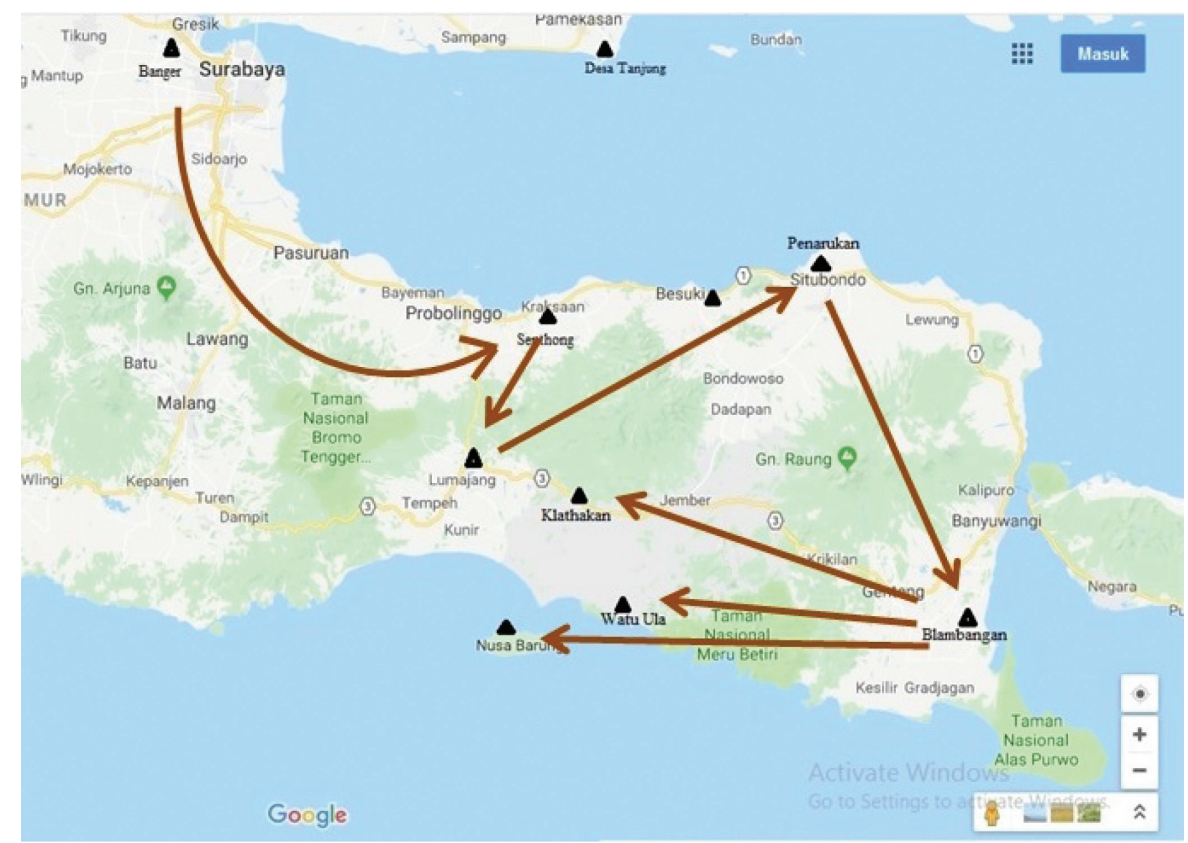

Gambar 1. Peta Penaklukan Wilayah oleh Belanda.

$\rightarrow$ : Arah penaklukan tentara kolonial terhadap wilayah-wilayah di Jawa. 
mahannya dapat diketahui bahwa naskah ini disalin ke dalam kertas folio bergaris berukuran $33,5 \mathrm{~cm} \times 21 \mathrm{~cm}$ dengan jumlah 69 halaman, setiap halaman terdiri dari 42 baris. Teks disalin ke dalam aksara Jawa menggunakan bahasa Jawa berbentuk tembang. Tinta yang digunakan berwarna hitam. Naskah telah lapuk dengan jilidan yang sudah rusak, kertas berwarna cokelat muda dengan bagian pangkal banyak yang sudah patah. Sampul naskah berwarna cokelat, dibungkus kertas minyak berwarna putih, dan disimpan dalam kertas bebas asam berwarna abu-abu.

Teks naskah Babad Basuki dan Bandawasa ini terdiri dari dua bagian yaitu Babad Basuki (halaman 1-29) dan yang kedua Babad Bandawasa (hal 31-69). Babad Basuki mulai disalin pada hari Sukra (Jumat), jam setengah sepuluh, tanggal 17 Jumadilakir 1302 Hijriyah atau Jumat 3 April, 1885 Masehi. Hal ini sesuai dengan informasi pada kolofon Babad Basuki yang ada di dalam pupuh I Tembang Asmarandana pada ke 2 yang berbunyi sebagai berikut : tatkalane kawula nulis, ing dinten Sukra punika, satengah sadasa wancine, ing tanggal ping pitulas, sasi Jumadilakirnya, tahun sewu triatus iku nenggih kekalih langkungnya.

Sementara kolofon teks Babad Bandawasa yang terdapat pada pupuh I Tembang $\mathrm{Ki}$ nanthi pada ke 4 dan 5 berbunyi (4) Nenggih duk lagya ginapus, tiba nujwa Rebo Pahing, wanci gathi atri awan, tanggal ping sangalikure, sasi Jumadilawalnya, tahun Be akhir winarni. (5) Sengkala dipunaneguh, sewu pitung atus iki, sawidak wolu langkungnya, tahun Welandi winarni, seuwu wolungatus ika, kawandasa ta ingkang wingking. Dari informasi di atas dapat dijabarkan bahwa Babad Bandawasa disalin pada hari Rabu Pahing, waktu jam setengah 3 siang, tanggal 29 Jumadilawal, tahun Be, 1768 Jawa atau 1840 Masehi. Informasi tahun penyalinan di atas masih belum tepat karena 1768 tahun Jawa jika dikonversi ke dalam masehi adalah tahun 1846 selisih 6 tahun dengan informasi di kolofon yang menyebutkan padanannya dalam tahun belanda yaitu 1840 . Tidak diketahui informasi nama penyalin dan tempat penyalinan naskah ini. Teks naskah ini sudah diterjemahkan oleh Komari dan dicetak menjadi buku Seri Naskah Kuna Nusantara No.16 oleh Perpustakaan Nasional Republik Indonesia tahun 2014.

Mula-mula, dalam cerita Babad Basuki, Belanda menguasai Senthong. Senthong adalah sebuah desa di Kecamatan Krejengan, Kab. Probolinggo yang berada di pesisir pantai utara. Pada Pupuh VI Tembang Asmarandana, pada 109 Senthong dinyatakan jatuh ke tangan kumpeni.

\section{Paran wus kabanda sami, mring bala kumpeni sira, Demang Wiradipura, amburu maring ing mengsah, kalawan sabalanya, kongsi mring Jember puniku, mungsuh sirna sedaya (Pupuh VI Asmarandana, pada 109) (Maka (prajurit Senthong yang kalah) diikat semua oleh tentara kompeni, Demang Wiradipura dan prajuritnya mengejar musuh yang melarikan diri sampai Jember, musuh sudah hilang)}

Selanjutnya pasukan kompeni melanjutkan penaklukan ke Lumajang. Lumajang saat ini adalah sebuah kabupaten di Jawa Timur. Lumajang berada di sebelah timur Taman Nasional Bromo Tengger Semeru. Pada pupuh ke VI Tembang Asmarandana, pada 131 Lumajang jatuh ke tangan Belanda.

Alami kang den perangi,

Negara Lumajang ika, cinatur cindheke bae, pan wus bedhah ing Lumajang, wus kena mring Walanda,

Kyai Tumenggung Banger Pasuruan bubar

(Pupuh VI Asmarandana, pada 131) (Lama perang berlangsung di Negeri Lumajang itu, singkat cerita sudah jatuh Lumajang ke tangan Belanda, Kyai Tumenggung Banger Pasuruan pulang ke tempat asalnya).

Dari Lumajang pasukan Belanda melanjutkan penaklukan ke wilayah yang di dalam teks disebut Penarukan. Penarukan saat ini masuk ke wilayah Kabupaten Situbondo. 
Terletak di pinggir pantai di sebelah timur Kecamatan Basuki. Saat ini tidak ada informasi mengenai nama Penarukan di Situbondo. Dalam daftar nama-nama kelurahan dan kecamatan yang termasuk wilayah Kabupaten Situbondo tidak ada nama Penarukan. Kemungkinan saat ini Watu Ula adalah nama sebuah dusun yang tidak masuk ke dalam daftar nama-nama desa atau kecamatan di bagian pesisir selatan Kabupaten Situbondo. Pada pupuh ke VI Tembang Asmarandana pada 138 Penarukan jatuh ke tangan Belanda.

\section{Saperaptanira sami, \\ Demang Tisman anut sigra, wus kaprentah ing Bangere, Ki Demang Tisman ta sira, sampun lami aprentah, mring tumenggung banger iku, sigegen ing Penarukan \\ (VI. Asmarandana 138)}

(Sesampainya (utusan Belanda dan Demang Basuki di Penarukan), Demang Tisman menyerah begitu saja di bawah kekuasaan Banger. Berhenti di Penarukan).

Dalam konteks teks di atas Banger merupakan pusat pemerintahan kolonial di wilayah timur Pulau Jawa. dalam tembang di atas dijelaskan bahwa Penarukan menyerah begitu saja di bawah kekuasaan Banger. Hal ini berarti secara tidak langsung Penarukan menyerah di bawah kekuasaan Belanda.

Setelah menaklukkan Penarukan, pasukan pemerintah kolonial melanjutkan 'petualangan'nya menaklukkan Blambangan. Blambangan saat ini merupakan sebuah kelurahan yang masuk ke dalam wilayah administratif Kecamatan Muncar. Kecamatan Muncar sendiri terletak di ujung timur Pulau Jawa berbatasan langsung dengan Selat Bali. Pada $p u-$ puh ke VI Tembang Asmarandana pada ke 142 Blambangan resmi jatuh ke tangan Belanda.

\author{
Cinatur cendhekireki, \\ kumpeni pan sampun menang, \\ wus bedhah Belambangane, \\ wus mulih para bupatya, \\ Madura panembahan,
}

\author{
Sumenep pangeranipun, \\ ing Mekasan tumenggungnya \\ (Pupuh VI Asmarandana, pada 142) \\ (Singkat cerita kompeni sudah menang, \\ sudah jatuh Blambangan, pulanglah \\ para bupati di antaranya Panembahan \\ Madura, Pangeran Sumenep, dan Tu- \\ menggung (Pa)mekasan).
}

Setelah menguasai Blambangan Babad Basuki menceritakan penaklukan wilayah Nusa, Klathakan, dan Watu Ula. Nusa dalam teks ini kemungkinan adalah Pulau Nusa Barung yang berada di sebelah selatan Pulau Jawa, di selatan Lumajang.

Tempat bernama Klathakan yang berada di wilayah bagian timur Pulau Jawa ada dua yaitu ada yang terletak di Kabupaten Jember dan Kabupaten Situbondo. Klathakan adalah sebuah desa yang berada di wilayah administratif Kabupaten Jember, lebih tepatnya di Kecamatan Tanggul. Sementara Klathakan yang berada dalam wilayah Kabupaten Situbondo adalah sebuah desa yang berada di Kecamatan Kendit.

Dalam daftar nama-nama kelurahan dan kecamatan di dalam wilayah Kabupaten Jember saat tidak ditemukan nama Watu Ula. Tetapi penelusuran melalui google map menunjukkan sebuah tempat bernama Watu Ula. Kemungkinan saat ini Watu Ula adalah nama sebuah dusun yang tidak masuk ke dalam daftar nama-nama desa atau kecamatan di bagian pesisir selatan Kabupaten Jember.

Selain penulisan sejarah secara kolonial dan penulisan sejarah nasional, sejarah Indonesia juga mengenal penulisan sejarah secara tradisional. Penulisan sejarah secara tradisional ini disebut babad. Babad secara harfiyah berarti 'cerita mengenai kejadian yang sudah terjadi.' (Poerwadarminta, 1939). Dalam sudut pandang penulisan sejarah tradisional kejadian-kejadian di dalam babad benar-benar terjadi namun dalam sudut pandang penulisan sejarah kolonial atau nasional perlu adanya penelitian lebih lanjut.

Penyebutan nama-nama tempat dalam Babad Basuki ini tidak berbeda dengan penyebutan nama-nama tempat dalam naskahnaskah tradisional lainnya. Misalnya dalam 
Panji Jayalengkara Sunyawibawa, seorang tokoh fiksi bernama Raden Jayalengkara disebut telah mengunjungi tempat-tempat seperti Gunung Pamriyan atau Gunung Merbabu (lihat Dwiadmojo, 2017). Ada juga seorang tokoh fiksi Sinangsaya dalam teks Gita Sinangsaya juga disebut telah mengunjungi Gunung Wilis, hingga Gunung Kampud atau Gunung Kelud (lihat Kurniawan, 2012: 4).

Sampai di sini terjadi semacam pembenturan antara fiksi dan fakta. Pembenturan yang terjadi adalah tokoh-tokoh fiksi yang diragukan keberadaannya di masa lalu dinarasikan mengunjungi tempat-tempat yang benar-benar nyata dan masih ada keberadaannya sampai sekarang. Hal ini tidak lain bertujuan untuk mendekatkan pembaca pada cerita dalam teks. Lewat pembenturan ini penyalin seolah ingin mengatakan bahwa kejadian-kejadian fiksi dalam babad ini benar-benar nyata.

Daerah-daerah yang disebutkan dalam teks ini merupakan wilayah yang penting. Hal ini dibuktikan dengan daerah-daerah tersebut ditaklukkan oleh Belanda. Setidaknya ada seorang penguasa lokal di daerah-daerah tersebut yang perlu ditaklukkan untuk menguasai wilayah timur Pulau Jawa. Seiring perjalanan waktu, dari abad ke 19 sampai sekarang, terjadi berbagai perubahan status daerah-daerah tersebut. Daerah-daerah tersebut saat ini ada yang menjadi kabupaten, kecamatan, desa, dan dusun. Dari informasi tersebut dapat dijelaskan bahwa perubahan status suatu daerah adalah sebuah keniscayaan.

\section{SIMPULAN}

Naskah Babad Basuki dan Bandawasa merupakan koleksi Perpustakaan Nasional Republik Indonesia dengan nomor koleksi $K B G$ 333. Teks naskah Babad Basuki dan Bandawasa ini terdiri dari dua bagian yaitu Babad Basuki (halaman 1-29) dan yang kedua Babad Bandawasa (hal 31-69). Babad Basuki mulai disalin pada hari Sukra (Jumat), jam setengah sepuluh, tanggal 17 Jumadilakir 1302 Hijriyah atau Jumat 3 April, 1885 Masehi. Babad Basuki meceritakan tentang asal-usul penduduk wilayah Basuki, penaklukan wilayah oleh pemerintah kolonial Belanda, dan kehidupan beberapa tokoh setelah penaklukan. Peta penaklukan wilayah di bagian timur Pulau Jawa dimulai dari Banger ke Senthong, dari Senthong ke Lumajang, berlanjut ke Penarukan, kemudian Blambangan. Dari Blambangan penaklukan dilanjutkan dengan penaklukan 3 wilayah sekaligus yaitu Nusa, Klathakan, dan Watu Ula.

\section{DAFTAR PUSTAKA}

BAKOSURTANAL. (2005). Pengertian Peta. (online). http://geografi-bumi.blogspot.com/2009/09/pengertian-peta. html (Hari Senin 3 Desember 2018 jam 22.00).

Behrend, T.E. (1988). Katalog Induk Naskahnaskah Nusantara Jilid 4 Perpustakaan Nasional Republik Indonesia. Jakarta: Yayasan Obor Indonesia.

Behrend, T.E. (1990). Katalog Induk Naskahnaskah Nusantara Jilid I Museum Sonobudoyo. Jakarta: Penerbit Jambatan.

Departemen Pendidikan Nasional. (2008). Kamus Besar Bahasa Indonesia. Edisi Keempat. Jakarta: Balai Pustaka.

Djajadiningrat. (1995). Tradisi Lokal dan Studi Sejarah Indonesia. Dalam Sudjatmoko, Ali, M., Resink, G. J. \& Kahin, G. Mc T. (Ed). Historiografi Indonesia, Sebuah Pengantar. Jakarta: Gramedia.

Dwiadmojo, GN. Watak Tembang Sumekar dalam Panji Jayalengkara Sunyawibawa (CS 104). Tesis tidak diterbitkan dalam Program Pascasarjana, Universitas Negeri Yogyakarta tahun 2016.

Ibrahim, Z. (Ed.). (1986). Sastera Sejarah, Interpretasi dan Penilaian. Kuala Lumpur: Dewan Bahasa dan Pustaka.

Kartodirdjo. (2001). Indonesian Historiography. Yogyakarta: Kanisius.

Komari. (2014). Babad Basuki dan Bandawasa (Deskripsi, Alih Aksara, dan Alih Bahasa). Jakarta: Perpustakaan Nasional Republik Indonesia.

Kuntowijoyo. (1999). Budaya dan Masyarakat. Yogyakarta: Tiara Wacana.

Kurniawan, A. Gita Sinangsaya: Suntingan Teks, Terjemahan, disertai Kajian Semiotika Riffaterre. Tesis tidak diter- 
bitkan dalam Program Studi Ilmu Sastra Jurusan Ilmu Humaniora, Fakultas Ilmu Budaya, Universitas Gajah Mada tahun 2012.

Poerwadarminta. (1939). Baoesastra Djawa. Batavia: J. B. Wolters Uitgevers Maatchappij N.V. Groningen.

Prihandito, A. (1998). Pengertian Peta. (online). http://geografi-bumi.blogspot. com/2009/09/pengertian-peta.html. (Hari Senin 3 Desember 2018 jam 22.00).

Raisz, E. (1948). Pengertian Peta. (online). http://geografi-bumi.blogspot. com/2009/09/pengertian-peta.html (Hari Senin 3 Desember 2018 jam 22.00).
Pudjiastuti, T. (2015). Menyusuri Jejak Kesultanan Banten. Jakarta: Wedatama Widya Sastra.

Wardhana dan Ilafi. (2017). Dari His(s)tory ke History: Naskah Jawa sebagai Sumber Penulisan Sejarah Asketisme Perempuan Jawa Abad XIX sampai Awal Abad XX. Makalah dalam Seminar Internasional Pernaskahan Nusantara, Festival Naskah Nusantara III di UNS, Surakarta tahun 2017 